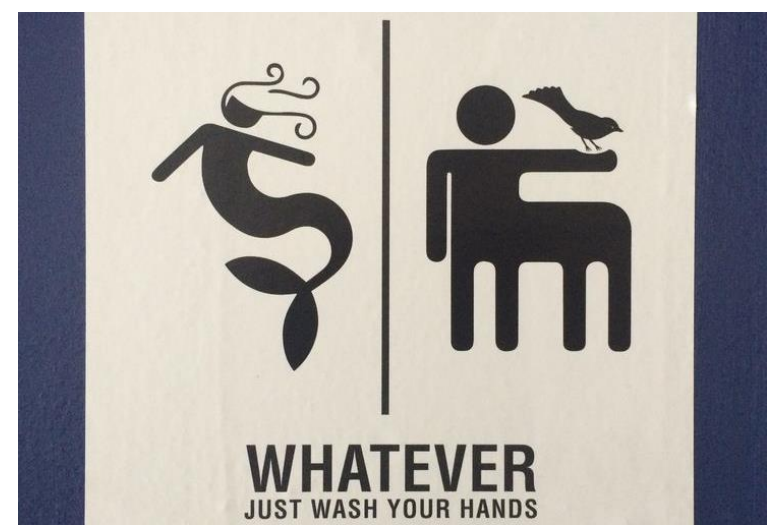

WC e gênero: discursos em movimento

WC and gender: discourses in motion

Aline Fernandes de Azevedo Bocchi ${ }^{1}$

Dantielli Assumpção Garcia ${ }^{2}$

Fernanda Pereira ${ }^{3}$

Karen Poltronieri ${ }^{4}$

Melissa Frangella Lozano ${ }^{5}$

Lucília Maria Abrahão e Sousa ${ }^{6}$

Resumo: A partir da perspectiva teórica da Análise de Discurso em articulação com as Teorias de Estudos de Gêneros, analisaremos como sentidos sobre as identidades de gêneros são constituídos e circulam em um conjunto de imagens de portas de banheiros. Nessas portas, funcionando como um modo de realização da ideologia dominante, atravessadas pelo funcionamento de diferentes aparelhos ideológicos, é possível perceber a sustentação de dizeres filiados à matriz heterossexual, a qual dicotomiza os gêneros em masculino e feminino. Ainda, nossas análises mostram que as portas de banheiros também podem ser o lugar de produção de sentidos outros para os gêneros, confirmando a tese de Pêcheux de que a ideologia é um ritual com falhas.

Palavras-chave: Análise de Discurso. Gênero. Portas de banheiros. Ideologia.

\title{
Abstract:
}

From the theoretical perspective of Discourse Analysis articulated with the Gender Studies Theories, this article intend to analyze how meanings about gender identities are constituted and circulate in a set of images of restroom doors. In these doors, it is possible to notice the support of sayings associated to the heterosexual matrix, working as the accomplishment of the dominant ideology, crossed by the functioning of different ideological apparatuses, which dichotomizes the masculine and feminine genders. Still, our analysis show that the bathroom doors can also be the place of production of other meanings for the genders, confirming Pêcheux's thesis that ideology is a ritual with failures.

Keywords: Discourse Analysis, Gender, Bathroom Doors, Ideology.

\footnotetext{
${ }^{1}$ Pós-doutoranda na Faculdade de Filosófia Ciências e Letras de Ribeirão Preto - USP, bolsista FAPESP, azevedo.aline@gmail.com. ORCID: https://orcid.org/0000-0003-4225-743X

${ }^{2}$ Docente do Programa de Pós-Graduação em Letras da Universidade Estadual do Oeste do Paraná UNIOESTE, Cascavel. E-mail: dantieligarcia@gmail.com. ORCID: https://orcid.org/0000-0002-88342253

3 Doutoranda no Programa de Pós-Graduação em Estudos da Linguagem - IEL/UNICAMP, fpereir@gmail.com. ORCID: https://orcid.org/0000-0001-9660-1414

${ }^{4}$ Graduanda do curso de Ciências da Informação e Documentação na Faculdade de Filosofia Ciências e Letras de Ribeirão Preto - USP, bolsista FAPESP, karen.poltronieri@usp.br. ORCID: https://orcid.org/0000-0001-8114-2091

5 Mestranda na Faculdade de Filosofia Ciências e Letras de Ribeirão Preto - USP, psimelissa.lozano@gmail.com. ORCID: https://orcid.org/0000-0001-7578-3319

${ }^{6}$ Docente no Programa de Pós-Graduação em Psicologia da Faculdade de Filosofia Ciências e Letras de Ribeirão Preto - USP, FAPESP, luciliamasousa@gmail.com. ORCID: https://orcid.org/0000-0002-45859287
} 


\section{Dizeres Iniciais}

Neste trabalho, da perspectiva teórica da Análise de Discurso articulada às Teorias de Estudos de Gêneros objetivamos analisar algumas portas de banheiro, buscando refletir acerca do modo como estas, ao dizerem que um banheiro é feminino e outro é masculino, funcionam como uma forma de realização da ideologia dominante de matriz heterossexual, no atravessamento de diversos aparelhos ideológicos (como a escola, a instituição médica, a Igreja, a família, ou seja, diferentes aparelhos que compartilham a mesma ideologia acerca dos gêneros). Os banheiros e suas portas, como mostraremos, ratificam os modos de pensar e viver os corpos centrados na matriz heterossexual e cisgênera.

Partindo da afirmação de Preciado (2006, s.p.) de que a arquitetura dos banheiros "parece simplesmente se pôr a serviço das necessidades naturais mais básicas (dormir, comer, cagar, mijar...) suas portas e janelas, seus muros e aberturas, regulando o acesso e a vista, operam silenciosamente como a mais discreta e efetiva das tecnologias de gênero", analisaremos um conjunto de imagens de portas de banheiro que intentam marcar "o feminino" e "o masculino", buscando compreender como uma indicação em uma porta ora estabiliza e ora faz ranger as relações entre os sujeitos em uma sociedade que se dicotomiza em homem e mulher, masculino e feminino. Para que tal objetivo seja alcançado, nosso texto divide-se em três partes. Na primeira, traçamos uma discussão em torno da ideologia (PÊCHEUX, [1975] 1997) e dos aparelhos ideológicos de Estado (ALTHUSSER, 1985). Em seguida, a partir de uma retomada de estudiosos do gênero (LAURETIS, 1994; SCOTT, 1995, HARAWAY, 2004; BUTLER, 2008), buscamos teorizar gênero. Por fim, trazemos a análise de algumas portas de banheiro, almejando explicitar como essas funcionam como como controladoras das identidades de gêneros.

\section{Ideologia e seus aparelhos}

Ao construir sua Teoria do Discurso, Michel Pêcheux (1996) se baseou no mesmo conceito de ideologia proposto pela releitura feita por Althusser: um conjunto de ideias que o sujeito compartilharia sem se dar conta e que produziria uma certa evidência ideológica, processo que cria(ria) uma verdade imaginária insubstituível sobre a existência material das relações do sujeito com a realidade. Diferentemente do conceito de ideologia em Marx, que seria um processo de mascaramento da realidade produzido pela classe dominante, para Althusser, a ideologia se realiza em discursos e práticas compartilhados por todos. Nesse sentido, tanto opressor quanto oprimido 
acreditariam nas mesmas coisas e é por esse motivo que a ideologia adquire tanta força. Assim, o sujeito diria o que diz porque realmente acreditaria naquilo que diz; ele não manipularia o discurso, apenas o reproduziria. Mas, se o sujeito não é consciente, o que é que dá a ele a sensação de ser a fonte do sentido, de ser dono daquilo que diz?

No texto "A Propósito da Análise Automática do Discurso: Atualização e Perspectivas" ([1969] 1997), Pêcheux e Fuchs explicam que o efeito leitor seria o responsável pela sensação de consciência do sujeito. E, para que esse efeito se realize, ele precisa estar dissimulado e esquecido para o sujeito:

Isto nos levará a reformular como uma das questões centrais a que se refere à leitura, ao efeito leitor como constitutivo da subjetividade, e caracterizado pelo fato de que, para que ele se realize, é necessário que as condições de existência deste efeito, estejam dissimuladas para o próprio sujeito (PÊCHEUX, FUCHS, 1997, p.164).

Quando Pêcheux fala em efeito leitor, ele não está se referindo à leitura escolar de tentar compreender o texto e reconhecer os caracteres, mas à leitura no sentido de forma de compreender o mundo e a compreensão que se faz do mundo a partir de uma determinada formação discursiva (FD) na qual se está inserido. Leitura para Pêcheux significa, portanto, ler o mundo: é aquilo que se compreende que o mundo seja. Por que as pessoas leem as coisas do jeito que leem, de onde vêm as coisas que elas falam, por que elas atribuem às coisas determinados sentidos? O sujeito não precisa ser letrado para fazer uma leitura do mundo. Uma pessoa não alfabetizada, por exemplo, também possui a compreensão de mundo que lhe é passada socialmente. Quando um sujeito lê um texto, portanto, ele diz o que esse texto significa e jura que é ele quem está produzindo essas conclusões: eu penso que, eu acredito que, etc. É esse efeito que cria a ilusão de que aquilo que lê pertence ao próprio sujeito, quando, na verdade, ele é que pertence à leitura que faz. Leitura e leitor têm a ver com atribuição de sentido ao mundo, com compreensão de mundo e essa compreensão tem origem na sociedade; por essa razão, ela antecede o sujeito.

Segundo os autores (PÊCHEUX, FUCHS, 1997), a questão do sujeito sofreu desvios nas pesquisas que foram feitas por aqueles que se propuseram a utilizar a Análise do Discurso (AD) a partir de 1969. Isso ocorreu porque havia um recalcamento e um mascaramento do Materialismo Histórico na academia, o que dificultava a articulação entre a teoria, a Linguística e a Teoria do Discurso. Era difícil evitar as traduções espontâneas do Materialismo Histórico que o transformavam em sociologia. 
As aplicações da AAD (Análise Automática do Discurso) desenvolvidas a partir de 1969 só se preocupavam com a parte social da língua, como subjetiva, espontânea e impondo o idealismo sobre o Materialismo Histórico, acreditando que ele poderia ser usado diretamente como instrumento. Pêcheux e Fuchs (1997) reconhecem que também corriam esse risco, pois também pertenciam à academia, mas pretendiam com o texto de 1969 aceitar as críticas e realizar as correções necessárias. Com esse objetivo, os autores situam a região do materialismo histórico adotada pela $\mathrm{AD}$ como "a da superestrutura ideológica em sua ligação com o modo de produção que domina a formação social considerada" (p.165). E a região da ideologia deveria ser caracterizada por uma materialidade específica articulada sobre a materialidade econômica, pois ela não está na esfera das ideias, acima do mundo das coisas e dos fatos econômicos:

o funcionamento da instância ideológica deve ser concebido como "determinado em última instância" pela instância econômica, na medida em que aparece como uma das condições (não econômicas) da reprodução da base econômica, mais especificamente das relações de produção inerentes a esta base econômica. A modalidade particular do funcionamento da instância ideológica quanto à reprodução das relações de produção consiste no que se convencionou chamar interpelação, ou o assujeitamento ideológico como sujeito ideológico, de tal modo que cada um seja conduzido, sem se dar conta, e tendo a impressão de estar exercendo a sua livre vontade, a ocupar o seu lugar em uma ou em outra das duas classes sociais antagônicas do modo de produção (ou naquela categoria, camada ou fração de classe ligada a uma delas). Esta reprodução contínua das relações de classe (econômica, mas também, como acabamos de ver, não econômica) é assegurada materialmente pela existência de realidades complexas designadas por Althusser como "aparelhos ideológicos do Estado", e que se caracterizam pelo fato de colocarem em jogo práticas associadas a lugares ou a relações de lugares que remetem às relações de classes sem, no entanto, decalcá-las exatamente (PÊCHEUX, FUCHS, 1997, p.166).

Dito de outra forma, é a ideologia que mantém as relações imaginárias com a produção que sustentam a instância econômica (ou o modo de produção). São as relações econômicas que determinam as ideologias dominantes. Pêcheux (1997) escreve que a ação da ideologia e seu funcionamento se dão pelo processo de interpelação ou assujeitamento do indivíduo. O sujeito está imerso numa formação social e numa formação ideológica (FI) geral (burguesa, neo-liberal, etc.) e há, dentro dessa ideologia geral, diferentes FIs. Segundo os autores, “cada formação ideológica constitui um conjunto complexo de atitudes e de representações que não são nem 'individuais' nem 
'universais' mas se relacionam mais ou menos diretamente a posições de classes em conflito umas com as outras" (PÊCHEUX, FUCHS, 1993, p.166).

Pêcheux e Fuchs (1997) explicam que é impossível, assim, separar a ideologia do discurso, pois o discurso é uma das instâncias materiais da ideologia. Fazer a separação seria recair em uma concepção idealista de ideologia acreditando que esta fica restrita ao mundo das ideias não afetando o mundo material. A ideologia geral se impõe, seja pelo discurso (repressão simbólica) ou pela repressão física. E, para que a ideologia geral consiga se impor, ela constitui aparelhos ideológicos (religião, família, escola, mídia) e repressivos (polícia, tribunal, exército) que partilham dela. Em Ideologia e aparelhos ideológicos de Estado (1985), como mostramos em Garcia, Camillo, Da Silva e Yado (2017, p. 92), Althusser afirma que, para manter sua dominação, a classe dominante gera mecanismos de perpetuação e/ou de reprodução das condições materiais, ideológicas e políticas de exploração e, para que essa dominação se efetive, o Estado passa a funcionar pelos seus aparelhos repressivos e ideológicos: "Dessa maneira, o Estado intervém ou pela repressão ou pela ideologia, tentando forçar a classe dominada a submeter-se às relações e condições de exploração" (GARCIA, CAMILLO, DA SILVA, YADO, 2017, p.92). Todavia, esses aparelhos, por sua vez, não são homogêneos, mas são constituídos por diferentes FDs relacionadas à ideologia geral. Ou seja, o aparelho ideológico religioso, por exemplo, poderá portar um discurso católico, protestante, espírita, evangélico, muçulmano, mas o discurso é, em linhas gerais, o mesmo: todos estão salvando almas, convertendo almas, levando para Deus, etc. Esse aparelho ideológico religioso é composto por uma pluralidade de FDs. Segundo os autores (PÊCHEUX, FUCHS, 1997, p.166),

as formações ideológicas [...] comportam necessariamente, como um de seus componentes, uma ou várias formações discursivas interligadas que determinam o que pode ou deve ser dito (articulado sob a forma de uma harenga, um sermão, um panfleto, uma exposição, um programa etc. ) a partir de uma posição dada numa conjuntura.

Ou seja, cada FD corresponde a uma FI e revela a sua forma de pensar e de ler o mundo. Existe todo um atrelamento dos AIEs com a FI geral e desta com as FDs. Cada grupo diz o que diz porque pensa de uma maneira e porque se identifica com uma FD. Retomando o exemplo do aparelho ideológico religioso, conclui-se que uma FI comporta várias FDs interligadas. A interpelação, ou o assujeitamento do indivíduo, apontado por Pêcheux como funcionamento da instância ideológica, é um chamamento. 
O sujeito é chamado a compartilhar aquilo que está socialmente posto e uma forma de ler o mundo que o precede. O meio no qual os sujeitos nascem os interpela a serem concordantes com um discurso que já existia. Por essa razão, Pêcheux usa o conceito de assujeitamento, pois o sujeito acredita e defende coisas e comportamentos da forma como são impostos. Em outras palavras, a FD interpela o sujeito na medida em que ele dá ouvidos a ela e é formado por ela. Como o sujeito não escolhe a que FD vai pertencer, ele é formado, educado e constituído por ela. Segundo os autores,

\footnotetext{
'a ideologia interpela os indivíduos em sujeitos': esta lei constitutiva da Ideologia nunca se realiza 'em geral', mas sempre através de um conjunto complexo determinado de formações ideológicas que desempenham no interior deste conjunto, em cada fase histórica da luta de classes, um papel necessariamente desigual na reprodução e na transformação das relações de produção, e isto, em razão de suas características 'regionais' (o Direito, a Moral, o Conhecimento, Deus etc....) e, ao mesmo tempo, de suas características de classe. Por esta dupla razão, as formações discursivas intervêm nas formações ideológicas enquanto componentes (PÊCHEUX, FUCHS, 1993, p.167, grifo dos autores).
}

A ideologia dominante vai se manifestar de diversas formas, em um conjunto de FIs, nos diferentes AIEs e suas FDs. Uma ideologia dominante que prega a inferioridade da mulher, por exemplo, produz FDs que permitirão o discurso de inferioridade da mulher na biologia, nas diferentes religiões, no sistema jurídico, na psicologia, etc. Nas ciências biológicas essa FD se materializaria em teorias que justificassem a inferioridade da mulher devido a sua estrutura física (diferença hormonal, massa muscular menor que a do homem, menor quantidade de neurônios, etc.). Já as ciências que tratam da área cognitiva (Psicologia, Neurologia, etc.) utilizariam dessas constatações biológicas para justificar a inferioridade da mulher devido à instabilidade emocional, provocada por variações hormonais, por exemplo. Essa aparente inferioridade física e instabilidade emocional feminina resultariam, então, na mulher como um ser incapaz juridicamente, desprovida de direitos civis, que precisa sempre de uma tutoria masculina capaz de decidir por ela. Há, assim, todo um conjunto de FDs materializando a mesma ideologia em relação à mulher.

Pensando também nas identidades de gênero, há, pelo funcionamento de uma ideologia dominante, um discurso que binariza as identidades dos sujeitos em masculino e feminino e justifica seus corpos. Isto é, por exemplo, no campo da biologia, a FD se materializa em dizeres como "homem tem pênis, logo, é masculino", "mulher tem 
vagina, logo, é feminina". Em um discurso que tem como elo o órgão sexual à identidade de gênero, a mulher trans que não fez a cirurgia de transgenitalização, logo que tem pênis, não é considerada mulher, pois seu corpo não traz uma vagina, mas sim uma marca, vista pelo discurso da biologia, como masculina. Do mesmo modo o homem trans que não tem o pênis e sim a vagina como órgão sexual.

Alguns aparelhos ideológicos como, por exemplo, a Igreja, a família sustentam esses dizeres que se inscrevem na matriz heterossexual que vigia os corpos e diz como esses devem ser para serem considerados masculinos ou femininos, mulher ou homem. Os aparelhos ideológicos, pensando o modo como fazem circular dizeres em torno da matriz heterossexual, cisgênera, ao interpelarem os indivíduos em sujeitos, acabam por controlarem os sujeitos, tentando impor suas identidades de gênero.

Para aprofundarmos nossa discussão, passemos à conceituação de gênero, para analisarmos como as portas fazem circular diferentes sobre as identidades dos sujeitos.

\section{Uma breve teorização acerca do conceito de gênero}

O conceito de gênero, em um sentido político, desenvolvido para contestar a naturalização da diferença sexual, como ressalta Haraway (2004, p. 211), foi articulado, teorizado no contexto dos movimentos de mulheres feministas do pós-guerra: “Apesar de importantes diferenças, todos os significados modernos de gênero se enraízam na observação de Simone de Beauvoir de que 'não se nasce mulher' e nas condições sociais do pós-guerra que possibilitaram a construção das mulheres como um coletivo histórico, sujeito em processo" (HARAWAY, 2004, p. 211).

Em 1963, a partir do Projeto de Pesquisa sobre Identidade de Gênero desenvolvido no Centro Médico para o Estudo de Intersexuais e Transexuais na Universidade da Califórnia, o psicanalista Robert Stoller no Congresso Internacional de Psicanálise, em Estocolmo, apresentou o termo "identidade de gênero". De acordo com Haraway (2004, p. 216), Stoller "formulou o conceito de identidade de gênero no quadro da distinção biologia/cultura de tal modo que sexo estava vinculado à biologia e gênero à cultura (psicologia, sociologia). O produto do trabalho da cultura sobre a biologia era o centro, a pessoa produzida pelo gênero - um homem ou uma mulher".

Joan Scott, historiadora norte-americana, em seu célebre artigo "Gênero: uma categoria útil de análise histórica", por meio da discussão de diferentes correntes (históricas) de pensamento, define gênero como elemento constitutivo das relações 
sociais baseadas nas diferenças percebidas entre os sexos e é uma forma primária de dar significados às relações de poder. Retomando os debates da historiadora, Louro (1997, p. 32) salienta que:

Desconstruir a polaridade rígida dos gêneros, então, significaria problematizar tanto a oposição entre eles quanto a unidade interna de cada um. Implicaria observar que o pólo masculino contém o feminino (de modo desviado, postergado, reprimido e vice-versa; implicaria também perceber que cada um desses pólos é internamente fragmentado e dividido (afinal não existe a mulher, mas várias e diferentes mulheres que não são idênticas entre si, que podem ou não ser solidárias, cúmplices ou opositoras).

Teresa Lauretis, importante estudiosa feminista, também aponta que a construção do gênero faz-se paradoxalmente por meio de sua desconstrução (LAURETIS, 1994, p. 209). Conforme a pesquisadora, o conceito de gênero não deve "estar preso" à diferença sexual a ponto de confundir com ela, fazendo com que, por um lado, o gênero possa ser incluído na diferença sexual "como efeito de linguagem, ou como puro imaginário - não relacionado ao real. Tal dificuldade, ou seja, a imbricação de gênero e diferença(s) sexual(ais) precisa ser desfeita e desconstruída" (LAURETIS, 1994, p. 208).

Ainda para Lauretis (1994, p. 209), gênero é uma representação construída historicamente, ocorrendo nos aparelhos ideológicos do Estado (ALTHUSSER, 1985): na mídia, na escolas, nos tribunais, nas famílias, na academia, na comunidade intelectual, nas práticas artísticas de vanguarda, nas teorias radicais: "O gênero, como o real, é não apenas o efeito da representação, mas também o seu excesso, aquilo que permanece fora do discurso como um trauma em potencial que, se/quando não contido pode romper ou desestabilizar qualquer representação" (LAURETIS, 1994, p. 209).

Portanto, na concepção de Lauretis (1994), gênero seria, como mostramos em Sousa e Garcia (no prelo), a representação de uma relação social, ou seja, o gênero representa um indivíduo por meio de uma classe (Lauretis retoma a discussão desenvolvida por Althusser em "Ideologia e Aparelhos Ideológicos do Estado"). Desse modo, para a feminista francesa, o gênero encontra-se "na esfera privada da reprodução, procriação e família, e não na esfera pública, propriamente social de superestrutura, onde a ideologia se insere e é determinada pelas forças econômicas e pelas relações de produção" (LAURETIS, 1994, p. 212). Assim, o gênero constitui os indivíduos, sendo 
uma instância da ideologia e do processo de interpelação que sustenta as relações de produção. Nas palavras de Lauretis (1994, p. 228):

A constituição do gênero ocorre através de várias tecnologias do gênero (p.ex. o cinema) [acrescentaríamos as portas dos banheiros objetos de nossas análises) e discursos institucionais (p. ex. a teoria) com poder de controlar o campo do significado social e assim produzir, promover e "implantar" representações de gênero. Mas os termos para uma construção diferente do gênero também existem nas margens dos discursos hegemônicos. Propostos de fora do contrato social heterossexual, e inscritos em práticas micropolíticas, tais termos podem também contribuir para a construção do gênero e seus efeitos ocorrem ao nível "local" de resistência, na subjetividade e na autorepresentação.

Butler (2003) também argumentará que o discurso da identidade de gênero "é intrínseco às ficções de coerência heterossexual" (HARAWAY, 2004, p. 219), o qual exigiria uma "coerência" entre um sexo e um gênero. Para a filósofa, o gênero, enquanto performance que produz sentidos aos sujeitos e a seus corpos, não é nem um conjunto, inscrito no corpo de significados culturais, nem a interpretação de um corpo sexuado, mas um conjunto de normas instituídas, mantidas e repetidas sobre o corpo que geram e tornam a pessoa viável ou inviável. Para Butler (2008, p. 25-26):

[...] a formulação de que a biologia é o destino, a distinção entre sexo e gênero atende à tese de que, por mais que o sexo pareça intratável em termos biológicos, o gênero é culturalmente construído: consequentemente, não é nem o resultado causal do sexo nem tampouco tão aparentemente fixo quanto o sexo. Assim, a unidade do sujeito já é potencialmente contestada pela distinção que abre espaço ao gênero como interpretação múltipla do sexo.

O conceito de gênero em Butler, como afirma Safatle (2015, p. 174), está potencialmente carregado de uma "teoria positiva da ação política", a qual "procura entender como sujeitos lidam com normas, subvertem tais normas, encontram espaços de singularidade produzindo novas formas.". Ainda nas palavras de Safatle (2015, p. 174):

Não se tratava de entender apenas como sujeitos são sujeitados às normas sociais e completamente constituídos por elas. Pois de nada adiantaria abandonarmos uma noção essencialista de natureza para cairmos em uma visão identitária de performatividade social. Por isto, pelas mãos de Butler, a teoria de gênero não será apenas uma teoria da produção de identidades. Ela será uma astuta teoria de como através da experiência de algo no interior da experiência sexual que não se submete integralmente às normas e identidades, descubro que ter um gênero é um "modo de ser despossuído", de abrir o desejo para aquilo que me desfaz a partir da relação ao outro. (SAFATLE, 2015, p. 174). 
Como mostraremos nas análises que se seguem, ao marcar-se nas portas dos banheiros "o masculino" e "o feminino", há uma tentativa de controle das identidades de gênero, impondo aos sujeitos, em sua relação eu-outro, normas para o convívio social. Nas portas, a descoberta de uma não contemplação das diversas identidades de gênero, uma vez que há a dicotomia, inscrita pela via do corpo, entre mulher-homem. Ao ir ao banheiro, a "descoberta" do sujeito de que se identificar com um gênero é um modo, muitas vezes, "de ser despossuído" de espaços em que suas identidades não sejam violentadas.

A partir das elaborações de Safatle, podemos considerar que a compreensão das marcações de gêneros nas portas de banheiros deve ir além da afirmação da sujeição às normas sexuais, pois os sujeitos não são completamente constituídos por uma ou outra identidade de gênero. Há sempre falhas nos processos de identificação, o que equivale a dizer que a identificação a um gênero nunca é completa ou acabada. Se pensarmos, com Pêcheux (1975), que a ideologia é um ritual com falhas, o ritual ideológico de atribuição de gênero falha justamente na produção de identidades fixas, estáveis e acabadas. É exatamente neste ponto que a contribuição de Butler encontra o pensamento de Pêcheux: pensar o gênero como um "modo de ser despossuído" pode ser uma forma de vislumbrar a contradição constitutiva do sujeito na relação incompleta com o gênero ao qual ele se identifica. Essas considerações complexificam a hipótese repressiva, dando maior consistência à reflexão a partir da teorização pecheutiana da ideologia. Os banheiros e suas portas participariam, assim, do ritual ideológico de atribuição de gênero na constituição do sujeito. Sua falha se situaria, justamente, na categoria de gênero como impossibilidade da completude da identidade de gênero.

\section{As portas dos banheiros: uma análise}

Preciado, em seu texto "Sujeira e gênero. Mijar/Cagar. Masculino/Feminino (2006), realiza um estudo e análise do funcionamento dos gêneros em relação às portas dos banheiros públicos e sua identificação para o "feminino" e o "masculino". De acordo com a autora, os sanitários públicos - como instituições burguesas generalizadas na Europa a partir do século XIX, inicialmente pensados como espaço de "gestão do lixo corporal" nos espaços citadinos, urbanos, convertem-se "progressivamente em cabines de vigilância do gênero". Como afirma (2006), essa nova "disciplina fecal", imposta pela burguesia do século XIX, é contemporânea ao "estabelecimento de novos 
códigos conjugais e domésticos que exigem a redefinição espacial dos gêneros e que serão cúmplices da normalização da heterossexualidade e da patologização da homossexualidade".

No século XX/XXI, os banheiros, considera Preciado (2006), tornam-se "células públicas de inspeção em que se avalia a adequação de cada corpo nos códigos vigentes da masculinidade e feminilidade". Como a pesquisadora pontua (2006), e mostraremos esse funcionamento neste nosso trabalho, na porta de cada sanitário, seja com masculino ou feminino, damas ou cavalheiros, um pêssego ou uma banana, um blá ou um blábláblá, uma interpelação de gênero:

\begin{abstract}
Não vamos aos banheiros para evacuar, senão para fazer nossas necessidades de gênero. Não vamos mijar, senão reafirmar os códigos da masculinidade e da feminilidade no espaço público. Por isso, escapar do regime de gênero dos banheiros públicos é desafiar a segregação sexual que a moderna arquitetura urinária nos impõe há mais ou menos dois séculos: público/privado, visível/invisível, decente/obsceno, homem/mulher, pênis/vagina, de-pé/sentado, ocupado/livre...

Uma arquitetura que fabrica os gêneros enquanto, debaixo do pretexto da higiene pública, diz ocupar-se simplesmente da gestão de nossas sujeiras orgânicas. SUJEIRA $>$ GÊNERO. Infalível economia produtiva que transforma a sujeira em gênero. Não nos enganemos: a máquina capital-heterossexual não desperdiça nada. Ao contrário, cada momento de expulsão de um dejeto orgânico, serve como ocasião para reproduzir o gênero. As inofensivas máquinas que comem nossas merdas são na realidade normativas próteses de gênero. (PRECIADO, 2006, s.p.)
\end{abstract}

Passemos às análises de algumas portas de banheiro para percebermos como essas reproduzem normativamente (a partir da matriz heterossexual) os gêneros, reafirmando as imagens da masculinidade e da feminilidade e as naturalizando.

No primeiro recorte (Figura 1), as frutas aparecem como forma de simbolizar, via verossimilhança, os gêneros, distinguidos entre o pêssego feminino e a banana masculina, fazendo referência justamente ao sexo como determinante do gênero. Do mesmo modo, no segundo recorte (Figura 2) temos uma garrafa de cerveja e um copo de drink formulando a relação entre órgãos sexuais e gêneros. Assim, o pêssego e copo de drink retomariam, por suas formas/desenhos semelhantes, a vagina/púbis, e a banana e a garrafa de cerveja, o pênis ereto. Entretanto, algo falha nesses processos de interpelação: o equívoco surge exatamente na presença das marcações $M$ (man) e W (woman) presentes no segundo recorte como tentativa de controlar a interpretação, tapar 
a possibilidade do mal-entendido. Essas marcações dão a ver justamente que a naturalidade da relação lógica direta entre sexo e gênero não é tão obvia assim.

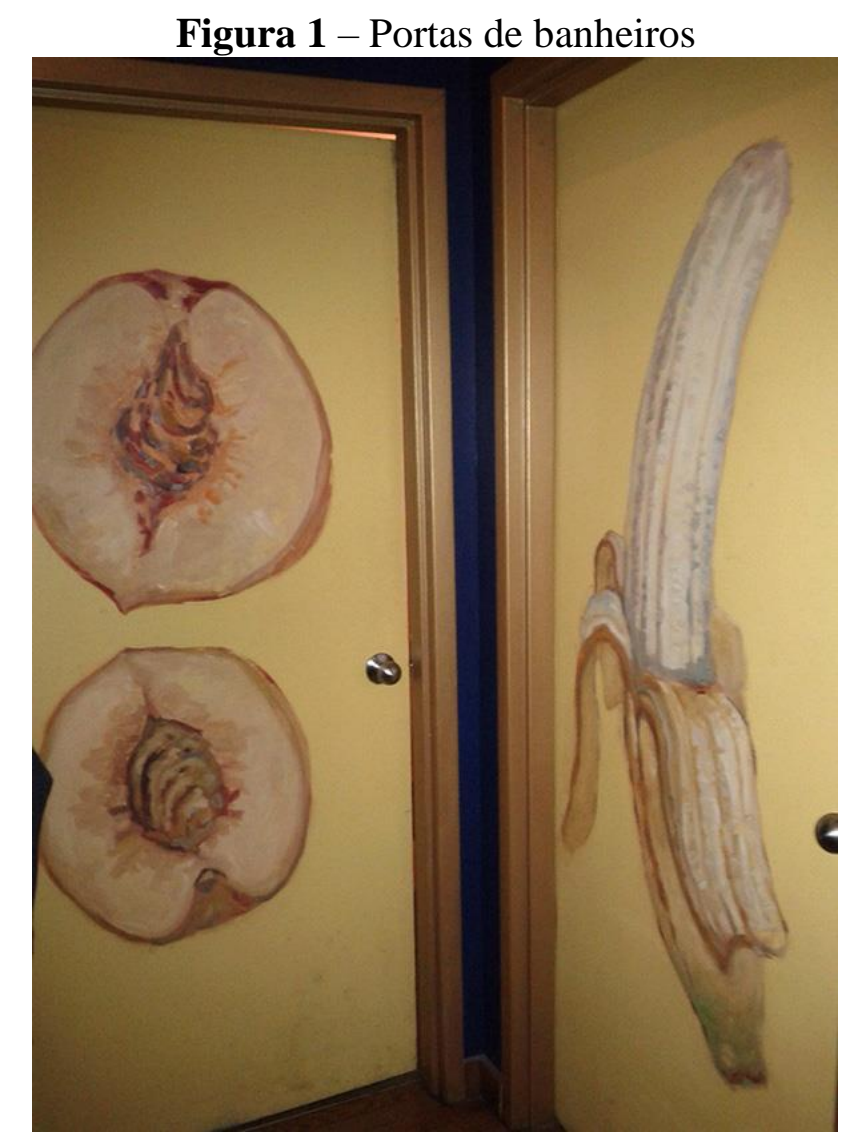

Fonte: Google Imagens

Figura 2 - Portas de banheiros

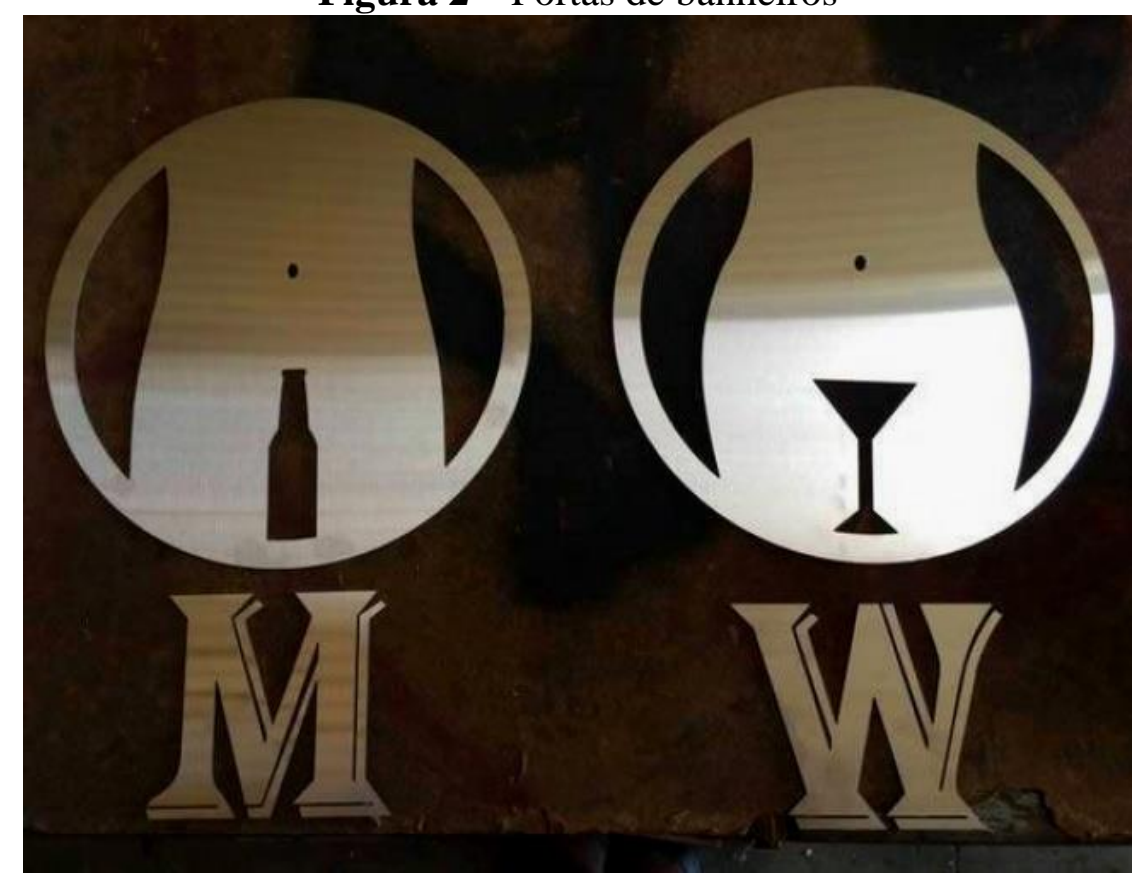

Fonte: Google Imagens 
Essas imagens mostram como a determinação biológica afirma o pertencimento a um gênero. Pelo funcionamento de uma memória (PÊCHEUX, 1999), está implícito que somente quem possui o órgão genital identificado socialmente como sendo do gênero masculino deveria utilizar a porta com uma banana ou uma garrafa desenhadas. E da mesma forma, apenas quem possuísse o órgão genital determinado socialmente como feminino poderia usar a porta que possui os pêssegos e o copo de drink. Há nessas portas-frutas-garrafas um apagamento/silenciamento dos sujeitos transexuais, travestis, intersexos. Questionamo-nos: que banheiro deveria utilizar a mulher trans que não realizou a cirurgia de transgenitalização e ainda possui como órgão sexual um pênis? Ou o homem trans que tem vagina? Pelas portas, a mulher trans deveria usar o banheiro masculino e o homem trans o feminino. Contudo, as posições desses sujeitos são inconciliáveis com a posição biologista na qual os gêneros são determinados por atributos sexuais, o que nos leva a supor que a eles é interditado um banheiro para usar, uma vez que não cumprem as normativas de gênero impostas pelos aparelhos ideológicos do Estado.

A indicação nessas portas não desconstrói a polaridade dos gêneros (LOURO, 1997), mas reproduz determinadas relações entre os sujeitos, interpelando os indivíduos e os identificando como pertencentes a um ou outro gênero. Não há uma abertura para experiências outras no interior dos corpos, gêneros e sexualidades, e sim um contrato heterossexual estabelecido, que dita o que pode e deve ser um banheiro para homem e mulher, criando um efeito ideológico imaginário de evidência que assegura o lugar de quem pode ou não entrar em tal banheiro. Como uma cabine de vigilância (PRECIADO, 2006) controla não só as identidades de gêneros como os sujeitos que não se identificam com a matriz heteronormativa que coloca o masculino ao homem e o feminino à mulher e os relaciona ao seu órgão sexual ${ }^{7}$. Ademais, nega-se também sua cidadania e seu direito de ser sujeito. Como afirma Bento (2014), ao analisar a questão do nome social

\footnotetext{
7 Como ressalta Jesus (2014), o transfeminismo tem questionado esse binarismo e essa relação direta entre órgão sexual e gênero. Nas palavras da estudiosa: "Mais raramente conhecido como feminismo transgênero, o transfeminismo pode ser definido como uma linha de pensamento e de prática feminista que, em síntese, rediscute a subordinação morfológica do gênero (como construção psicossocial) ao sexo (como biologia), condicionada por processos históricos, criticando-a como uma prática social que tem servido como justificativa para a opressão sobre quaisquer pessoas cujos corpos não estão conformes à norma binária homem/pênis e mulher/vagina, incluindo-se aí: homens e mulheres transgênero; mulheres cisgênero histerectomizadas e/ou mastectomizadas; homens cisgênero orquiectomizados e/ou emasculados; e casais heterossexuais com práticas e papéis afetivossexuais divergentes dos tradicionalmente atribuídos, entre outras pessoas. O transfeminismo é uma categoria do feminismo em construção, a qual emerge como resposta teórica e política à falha do feminismo de base essencialista, comumente biológica, em reconhecer o gênero como uma categoria distinta da de sexo, o que reforça estereótipos sobre os corpos". (JESUS, 2014, p. 243).
} 
enquanto norma que estabelece o respeito às identidades de gênero e uma cidadania precária, pois representa uma dupla negação: a condição humana e de cidadão/cidadã de sujeitos que carregam no corpo determinadas marcas:

Essa dupla negação está historicamente assentada nos corpos das mulheres, dos/as negros/as, das lésbicas, dos gays e das pessoas trans (travestis, transexuais e transgêneros). Para adentrar a categoria de humano e de cidadão/cidadã, cada um desses corpos teve que se construir como "corpo político". No entanto, o reconhecimento político, econômico e social foi (e continua sendo) lento e descontínuo. (BENTO, 2014, p. 167).

Podemos perceber que nas portas analisadas não há o reconhecimento dos corpos trans. Nelas, esses sujeitos e seus corpos políticos não são materializados, mas apagados em favor do binarismo homem-pênis, mulher-vagina.

O sujeito ao deparar-se diante de duas portas de banheiro, uma reservada aos sujeitos portadores de vagina e outra reservada aos portadores de pênis, é forçado a realizar uma escolha que denuncia sua condição biológica, apesar de sua identidade de gênero. Ou seja, existe um regime de vigilância sobre os corpos que permite aos outros produzirem dizeres sobre aqueles que não se encaixam nessa FD dicotômica, deixandoos à margem, em um não lugar.

Mas será que as duas portas a seguir comportariam outras identificações de gênero? Seria possível que apenas com a autorização de entrada desses gêneros ali listados houvesse a inclusão e o sentimento de pertença dos sujeitos que ali atravessam? No entanto, é importante observar esse movimento. Houve ali uma tentativa de inclusão. Que tentativa foi essa? Seria devido ao momento histórico de lutas do sujeitos que não se identificam com a cisgeneridade no qual vivemos? Seria a emergência de uma nova ideologia? Além disso, é importante pontuar o ambiente no qual esse placa se inclui: Um Museu Cultural, um espaço de circulação de pessoas e debates.

Outro ponto que chama a atenção está nos outros adjetivos que foram incluídos ali e que nada tem a ver com a indicação de gênero, mas que indicam o sentido de diversidade. Como se aquele banheiro comportasse "todas" as diferenças existentes hoje em nossa sociedade.

Também não escapa a nós a escolha das figuras de representação de Tarsila do Amaral e Adoniram Barbosa, dois sujeitos que viveram em um determinado contexto histórico, no qual essas diferenças, mesmo existindo, não eram escutadas quando muitos 
dos corpos eram silenciados havendo pouco espaço para os que não se encaixavam nos moldes heterossexuais.

Figura 3 - Portas de banheiros

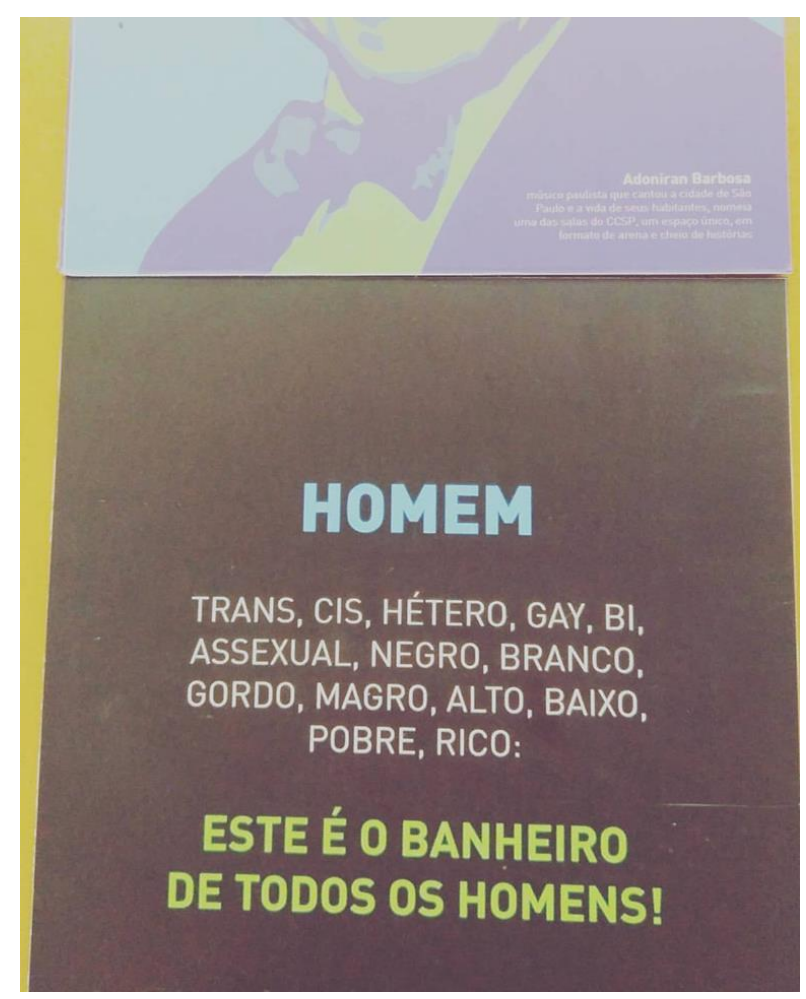

Fonte: Porta do Centro Cultural São Paulo

Figura 4 - Portas de banheiros

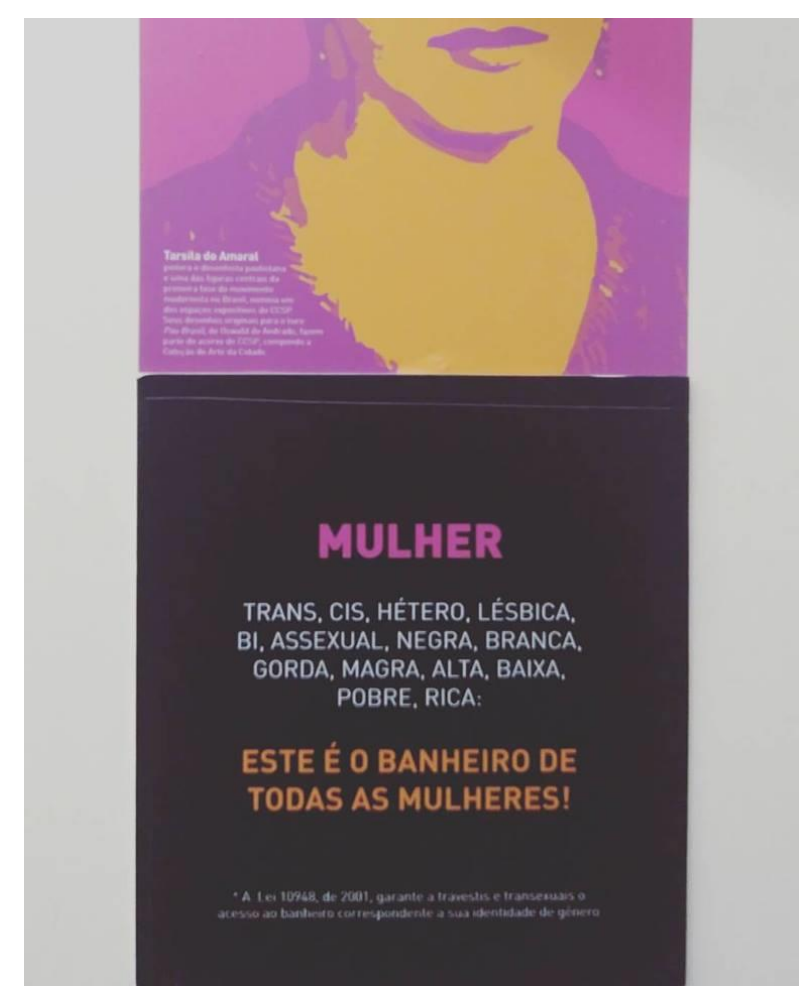

Fonte: Porta do Centro Cultural São Paulo 
Vejamos mais duas outras portas, também sustentadas na matriz heterossexual, contudo, não nos corpos dos sujeitos, mas em imaginários acerca do que significa ser homem e ser mulher. Em um jogo de imagens, as portas fazem circular dizeres que colocam a mulher como falante e o homem como lacônico.

Figura 5 - Portas de banheiros

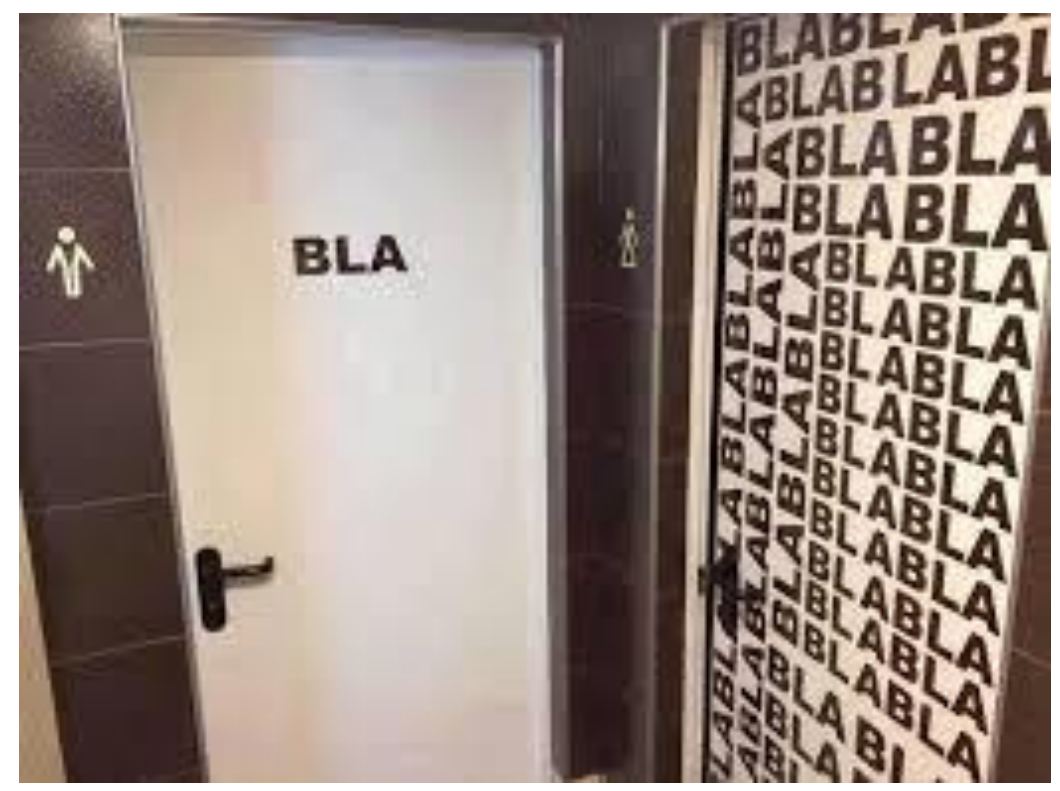

Fonte: Google Imagens

Figura 6 - Portas de banheiros

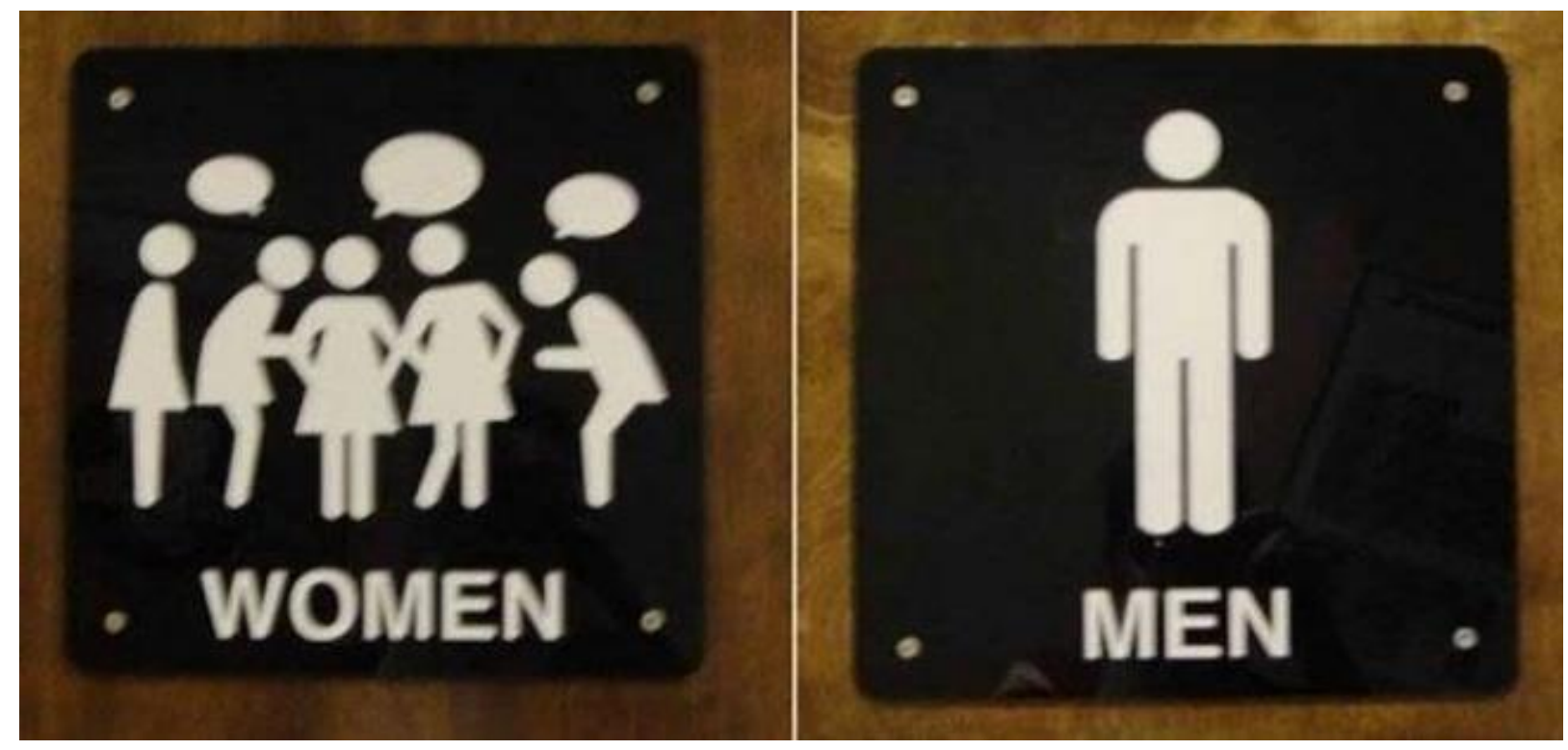

Fonte: Google Imagens 
Nessas portas, temos em circulação sentidos esperados aos sujeitos, os quais estão relacionados ao que se espera do homem e da mulher (observemos que além das marcas de "Bla" e "BlaBlaBlaBla...", dos balões de conversas há também nas portas desenhos de um homem e de uma mulher - como uma forma de controlar os corpos e indicar qual seria o sentido e os sujeitos esperados dessas portas). Temos em funcionamento imagens como "mulher fala demais", "mulheres fazem fofoca", "homem são mais diretos", "falam menos" ou "não falam" (por isso demorariam menos quando vão ao banheiro, uma vez que vão sozinho e as mulheres, como vemos, vão em grupo para poderem "fofocar"). Tais efeitos ideológicos, sustentados e repetidos como únicos e óbvios, interpelam os indivíduos em sujeitos de seus discursos e passam a produzir a certeza de um sentido estabilizado para a realidade, sentido este dominante que não pode nem deve ser desambiguizado.

As portas dos banheiros culminam em uma classificação e encaixotamento de sentidos atribuídos a cada gênero, não tendo a opção de não pertencimento (pois há o desenho indicando a qual pertencer). As portas retomam, desse modo, sentidos sustentados historicamente aos sujeitos homens e mulheres. Mais uma vez apagam outros corpos que não se identificariam com esse funcionamento. Em "A Dominação Masculina”, Bourdieu (2016) explica que, ao longo da história, a diferença anatômica, como justificativa natural da diferença entre os gêneros, produziu, em diferentes culturas, efeitos de sentido negativos para o feminino: "a mulher estando constituída como uma entidade negativa, definida apenas por falta [...]” (BOURDIEU, 2016, p.45). Em outras palavras, ao fazer a relação pênis-ereção-virilidade, características físicas/psicológicas opostas (mole, curvo, úmido, baixo, fechado, cheio, fertilidade, sensibilidade, fragilidade, etc.) passam a ser compreendidas como femininas e adquirem valor negativo, produzindo efeitos de sentido indesejáveis sobre a mulher e a feminilidade. No caso das portas analisadas, as figuras 3 e 4 colocam a capacidade comunicativa como algo exclusivo do feminino e, portanto, negativo, produzindo um efeito de sentido jocoso quando os sujeitos se deparam com essas portas. Isso é possível, como já discutido anteriormente, devido ao fato de que todos compartilhamos dessa ideologia, que é reproduzida e sustentadas pelos AIEs.

Assim, esses sentidos negativos a cerca do feminino seguem sendo propagados. Nas portas abaixo (figuras 7 e 8 ), o feminino aparece representado pela falta, pela ausência: 
Figura 7- Portas de banheiros
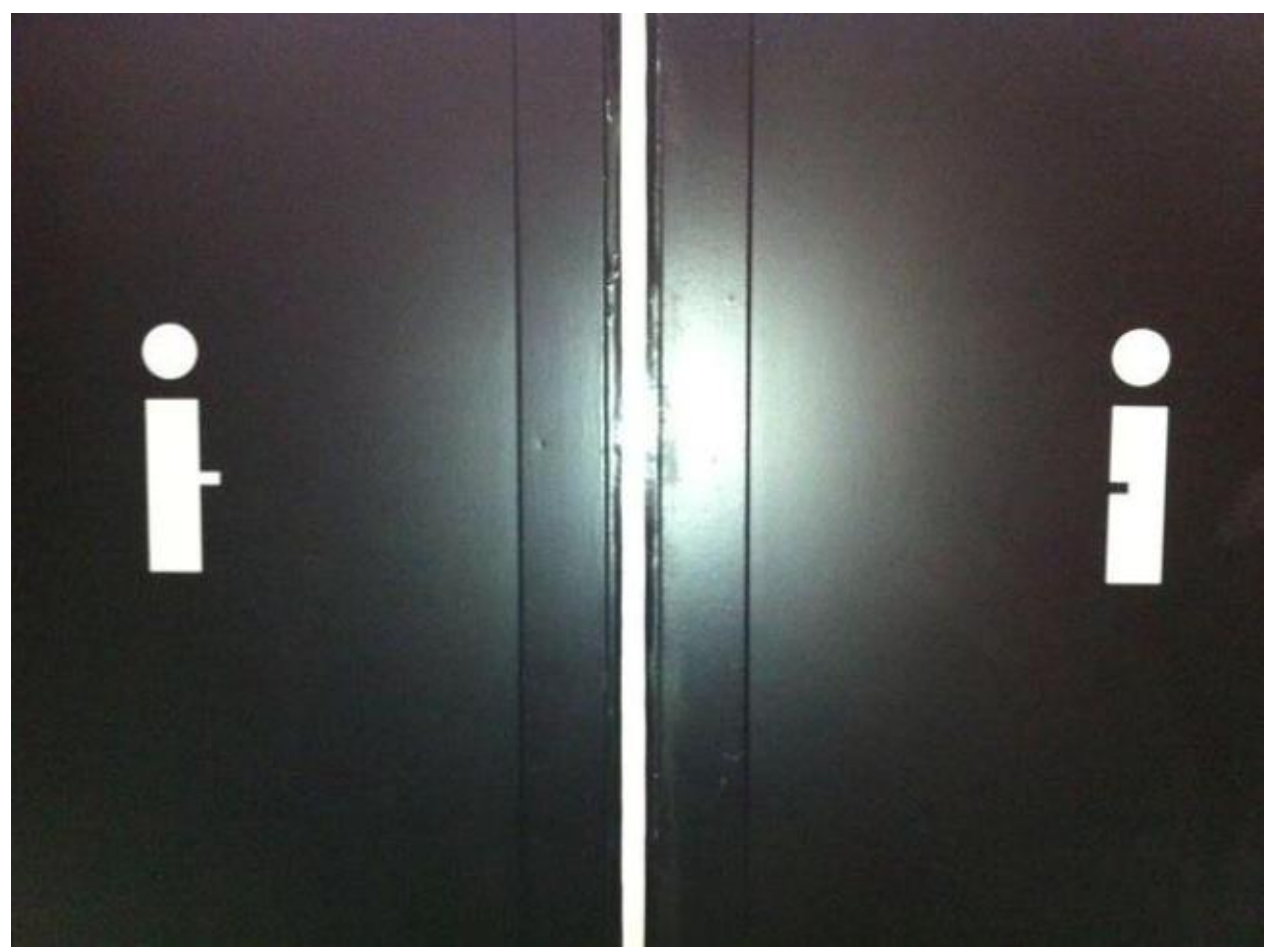

Fonte: Google Imagens

A porta analisada traz a representação do sujeito como a letra "i" do alfabeto, e a diferenciação biológica continua presente, pois, em uma delas, a letra "i" possui um traço horizontal que retoma a memória do masculino como possuidor de um algo a mais, o pênis. No entanto, a segunda porta traz a imagem de um "i" faltado um pedaço, retomando uma memória do feminino como a falta. Nesse sentido, o aparelho ideológico em questão reproduz um discurso no qual a mulher aparece como um sujeito incompleto, em que algo lhe falta, e o homem como completude (ou como aquele que viria a completá-la). Não bastava apenas representar a segunda porta sem o traço/pênis, pois a memória que é retomada é de que a mulher é incompleta, falha, negativa, desprovida de sexo, e que precisaria do homem para completá-la, pois é ele o possuidor do pedaço que está faltando na imagem. Ou seja, o homem tem um a mais que lhe confere um órgão que tanto se combina com o imaginário de poder atribuído ao pênis; nesses termos, temos a presença/ ausência de sinal que encerra o imenso campo das distinções apenas como diferenciação de órgão sexual entre homem e mulher, silenciando outras maneiras de dizer sobre a questão. 
A porta da figura 6 abaixo representa o feminino (girls) como um cachorro quente sem a salsicha, ou seja, sem a sua parte de maior valor, sem aquilo que o caracteriza como um cachorro quente. Assim o masculino (boys) é colocado novamente acima do feminino, como algo melhor, de maior valor, um cachorro quente completo.

Figura 8 - Portas de banheiros
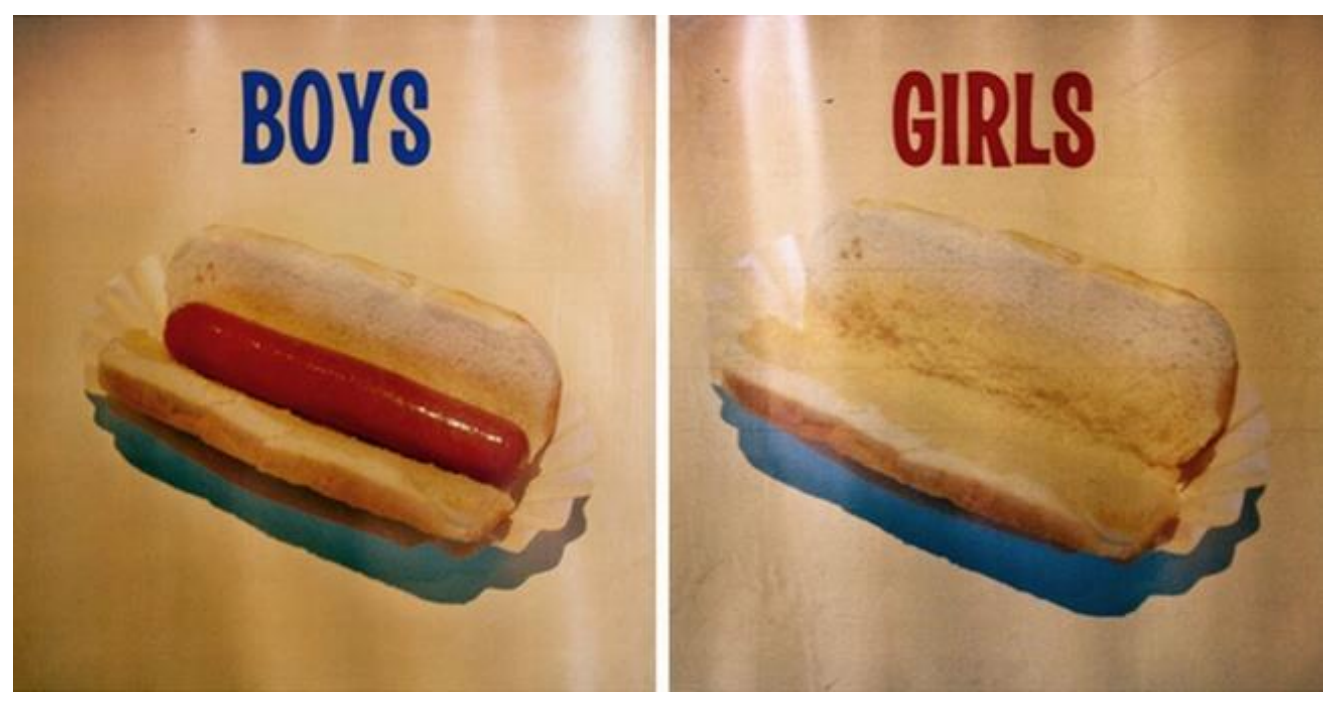

Fonte: Google Imagens

A mulher como ser incompleto por não possuir um pênis, segundo Kehl (2016), é uma fantasia infantil construída durante a passagem pelo complexo de Édipo, no qual a angústia da castração produz no menino a ideia de completude em comparação com a menina. A falta (angústia), parte constitutiva do sujeito, é sentida pela criança que associa sua completude a possuir ou não aquela parte do corpo. No entanto, a falta não é exclusiva do feminino, mas faz parte da constituição de todos os sujeitos, e "[...] em análise, qualquer sujeito descobre que um falo não é um pênis.” (KEHL, 2016, p.217).

A autora explica que o pênis, durante a infância, é associado a esta completude (objeto do desejo capaz de obturar a falta), porém, o falo (dentro da teoria psicanalítica) não se resume ao órgão sexual masculino, mas àquilo que é valorizado por uma sociedade em um determinado momento histórico (beleza física, poder, dinheiro, sucesso, etc.), ou seja, a instauração de novas faces do falo na cadeia simbólica. Segundo Kehl (2016, p.159), “[...] o falo, simbolizável a partir de qualquer objeto ao qual uma cultura atribua valor, não pertence a sujeito nenhum, mas está ao alcance de todos". Portanto, portar um pênis não é condição suficiente para se ter um falo, "o que deveria lançar o menino, na teoria psicanalítica, a uma condição tão incerta quanto a da 
menina" (KEHL, 2016, p.165). Assim, as portas de banheiro, ao reproduzirem a imagem da mulher como incompleta, silenciam o fato de que "a castração simbólica incide sobre homens e mulheres, e, portanto, a mulher não é um sujeito menos alguma coisa (p.189)", nem o homem possui algo a mais, ou algo melhor que a mulher, ambos compartilham a mesma condição humana.

Além disso, as duas figuras analisadas seguem reproduzindo a ideologia dominante, que polariza a divisão de gêneros, confirmando que as representações das portas de banheiros constituem um aparelho ideológico, conforme já demonstrado, que regula os corpos, determinando o seu comportamento, forçando os sujeitos que não se encaixam nesta dicotomização a denunciarem sua condição biológica publicamente.

Esta denúncia, além de dar ao outro, dentro da ordem do discurso, permissão para produzir dizeres carregados de sentidos negativos sobre esses corpos à margem, também produz dor e sofrimento. O documentário "Se Essa Escola Fosse Minha", produzido por Fellipe Marcelino e Letícia Leotti, em 2017, apresenta relatos de situações de violência vivenciadas por estudantes LGBT no ambiente escolar, dentre as quais a questão da utilização dos banheiros públicos. Para os estudantes, o banheiro é um lugar que eles procuram evitar para não passarem por situações constrangedoras como: Serem retirados do banheiro pelas autoridades escolares; Os demais alunos ficarem do lado de fora do banheiro esperando que saiam; Terem que utilizar o banheiro em horários específicos diferente dos demais alunos; Ou até a proibição de usarem os banheiros da escola. Além disso, essas situações acabam por permitir que os demais sujeitos questionem sua sexualidade, sua identidade de gênero, ou seja, expõe publicamente algo muito íntimo que está situado na esfera privada da vida de qualquer sujeito. Em um dos depoimentos, fica evidente o funcionamento do aparelho ideológico repressor, que expõe e marginaliza esses corpos, quando uma das alunas relata ${ }^{9}$ que "Enquanto as crianças LGBT não sabem nem o que são, elas já estão sofrendo a violência.", uma violência simbólica, constante, compartilhada por todos, e reproduzida no interior desse AIE que é a escola. No entanto, para a $\mathrm{AD}$, sempre há um mecanismo de resistência, de ruptura, frente à ideologia dominante e os AIEs. Pêcheux (2015) explica que essa ruptura independe de um sujeito inteligente, consciente e empírico, mas ocorre pela manifestação do inconsciente, por meio dos atos falhos, dos chistes, do lapso, produzindo a contradição, a falha no ritual de interpelação, expondo aquilo que

\footnotetext{
${ }^{8}$ Disponível em: https://www.youtube.com/watch?v=NHJMDuhruz8. Acesso em 26 de jan. 2018.

${ }^{9}$ Documentário "Se Essa Escola Fosse Minha", trecho a partir de 19:00 min.
} 
não poderia ser dito (representado, materializado). Em nosso objeto de análise, essa resistência aparece nas portas de banheiros que utilizam do humor para representarem banheiros unissex (ou banheiros para todos os gêneros), como as expostas pelas figuras 9 e 10 abaixo:

Figura 9 - Portas de banheiros

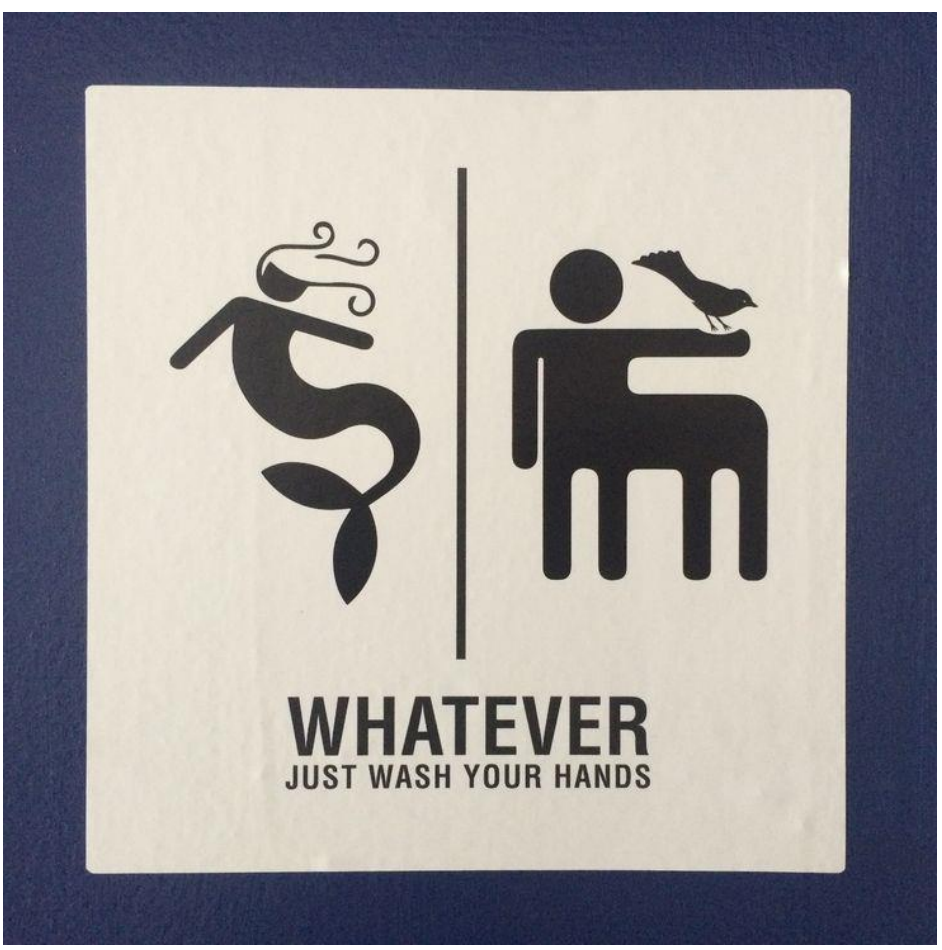

Fonte: Google Imagens

A figura 9 mostra uma placa de banheiro trazendo imagens que aparentemente seriam de uma sereia e um centauro. Logo abaixo da imagem, aparece escrito em inglês: “Tanto faz. Apenas lave as mãos. ${ }^{10 "}$. Ao retomar a memória de seres híbridos da mitologia grega, a figura na porta produz efeito cômico quando nos damos conta de que não importa (ou tanto faz) quem pode utilizar esse banheiro, pois até esses seres míticos poderiam utilizá-lo. O mais importante seria lavar as suas mãos após utilizá-lo, remetendo a ideia de que muitas pessoas não o fazem. Aqui, ao produzir esse sentido cômico, a porta rompe com a ideologia dominante, tirando o foco discussão sobre a identidade de gênero de quem usa o banheiro, e colocando no ponto de higiene pessoal.

A resistência também aparece nas portas representadas pela figura 10, abaixo, pois, ao ir ao banheiro, o sujeito se depara com duas possibilidades: um unicórnio ou um monociclo:

10 Whatever. Just wash your hands. 
Figura 10 - Portas de banheiros

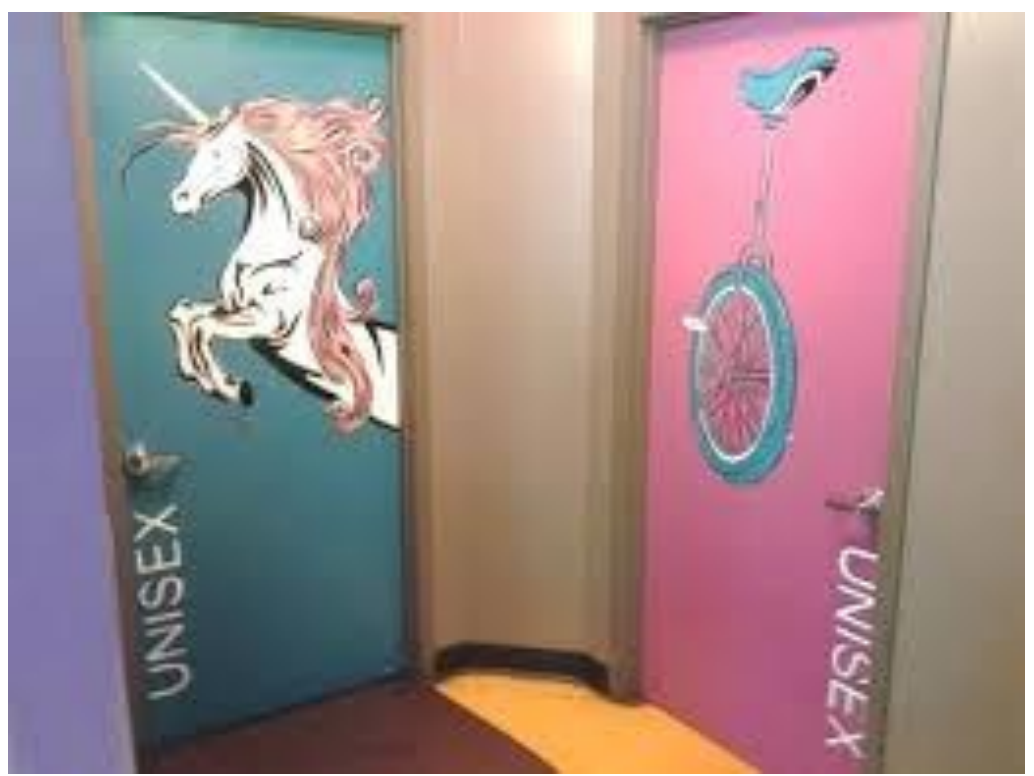

Fonte: Google Imagens

Novamente, ao ter que escolher entre um animal mitológico e um instrumento de transporte utilizado em apresentações de equilíbrio, o sujeito é deslocado para fora da ação desses banheiros, produzindo sentidos outros que os produzidos pela divisão sexual dos gêneros.

As portas representadas pelas figuras 9 e 10, ao não colocarem a questão do órgão sexual como determinante da identidade de gênero, desconstroem a polarização imposta pelo AIE, problematizando a questão. Além disso, permitem que os sujeitos colocados à margem encontrem um lugar, que lhes é negado dentro desse mecanismo. Polemizam e poetizam os efeitos do que seja feminino e masculino, provocando outros efeitos de sentido sobre atributos que podem ser endereçados a qualquer gênero sem uma definição cristalizada pela ideologia dominante. Cavalo alado, Pégaso, monociclo, sereia, centauro, pássaro e cabeleira indiciam o estatuto de "unissex", ou seja, convocam o sujeito a outros modos de significação para que escolhas possam ser produzidas, desenroladas e produzidas pelo sujeito diante da porta. Onde o desejo mora e onde a captura ideológica interpela o sujeito em sua relação com o poder: esse é o lugar para o qual a porta aponta.

\section{Considerações Finais}

Buscamos mostrar neste trabalho, ao analisarmos imagens de portas de banheiros, como sentidos sobre as identidades de gêneros são produzidos. Sentidos 
sustentados pelo funcionamento dos aparelhos ideológicos de Estado, potentes e eficazes que regulam os gêneros e seus sujeitos. Ao fixar o nome dos viventes, os aparelhos definem o que é homem e mulher, o sexo com que se nasce e se registra um bebê, o nome que se tem de nascimento, mais adiante, são eles também que produzem a autorização para usar um nome social e uma mudança de gênero etc. Desse modo, como mostramos em nossas análises, as portas dos banheiros funcionam como um dispositivo que segue as coordenadas dos aparelhos ideológicos, que asseguram e confirmam o funcionamento das identidades de gêneros identificadas com a matriz heterossexual. Contudo, todo o ritual ideológico é passível de falha e outros sentidos e portas também emergem e fazem ranger a estrutura que sustenta a cisgeneridade, o masculino e o feminino como as únicas formas de identificação dos sujeitos.

\section{Referências Bibliográficas}

ALTHUSSER, L. Aparelhos Ideológicos do Estado: nota sobre aparelhos ideológicos do Estado. Rio de Janeiro: Edições Graal, 1985.

BENTO, B. Nome social para pessoas trans: cidadania precária e gambiarra legal. Contemporânea - Revista de Sociologia da UFSCar, São Carlos, v. 4, n. 1, jan-jun. 2014, pp. 165-182.

BOURDIEU, Pierre. A Dominação Masculina. A condição feminina e a violência simbólica. $3^{\circ}$ ed. Rio de Janeiro: Edições Best Bolso, 2016.

BUTLER, J. Problemas de gênero: feminismo e subversão da identidade. Rio de Janeiro: Civilização Brasileira, 2008.

GARCIA, D. A.; SOUSA, L. M. A. e. Efeitos de batom na fotografia, \#MEDEIXA, a mulher e o corpo dela. (no prelo)

GARCIA, D. A.; CAMILLO, E. DA SILVA, J. R. B.; YADO, T. H. M. A cruz, a foice e o martelo: ideologia e aparelhos ideológicos de Estado discursivizados no filme Ida. In: SOUSA, L. M. A e.; GARCIA, D. A. Ler Althusser hoje. São Carlos: EDUFSCAR, 2017.

HARAWAY, D. "Gênero" para um dicionário marxista: a política sexual de uma palavra. Cadernos Pagu. (22), 2004, pp.201-246.

JESUS, J. G. de. O conceito de Heterocentrismo: um conjunto de crenças enviesadas e sua permanência. Psico-USF, Bragança Paulista, v. 18, n. 3, p. 363-372, set/dez 2013

KEHL, Maria Rita. Deslocamentos do feminino: a mulher freudiana na passagem para a modernidade. 2.ed. São Paulo: Boitempo, 2016.

LAURETIS, T. de. [1986]. A tecnologia do gênero. In: HOLLANDA, H. B. de. (Org.). Tendências e impasses: o feminismo como crítica da cultura. Rio de Janeiro: Rocco, 1994.

LOURO, G. L. Gênero, sexualidade e educação. Uma perspectiva pós-estruturalista. Petrópolis: Vozes, 1997. 
MILNER, J-C. O amor da língua. Trad. Ângela Cristina Jesuíno. Artes Médicas. Porto Alegre, 1987.

ORLANDI, E. A ordem da língua e dêixis discursiva (uma crítica ao linguisticamente correto). In: ORLANDI, E. Eu, Tu, Ele: Discurso e real da História. Campinas: Pontes, 2017.

Discurso em análise: sujeito, sentido, ideologia. Campinas: Pontes, 2012.

ORLANDI. Análise do discurso: princípios e procedimentos. 7 ed. Campinas: Pontes, 2009.

PÊCHEUX, M. O Discurso: estrutura ou acontecimento. $4^{\circ}$ ed. Campinas: Pontes, 2006.

[1975]. Semântica e discurso: uma crítica à afirmação do óbvio. Campinas: Editora da Unicamp, 1997.

O mecanismo do (des)conhecimento ideológico. (p.143 a 152). In: ŽIŽEK, Slavoj (org.). Um mapa da ideologia. (Trad. Vera Ribeiro). 1.ed. Rio de Janeiro: Editora Contraponto, 1996.

; FUCHS, C. A propósito da Análise Automática do Discurso: atualização e perspectiva. In: GABET, F.; HAK, T. Por uma análise automática do discurso: uma introdução à obra de Michel Pêcheux. Campinas: Editora da Unicamp, 1997. Pontes, 1999.

Papel da memória. In: ACHARD, P. [et.al.]. Papel da memória. Campinas:

O Discurso: Estrutura ou acontecimento? Trad. Eni Puccinelli Orlandi. $4^{\circ}$ ed. Campinas / SP: Pontes Editores, 2015.

PÊCHEUX, M. O discurso: estrutura ou acontecimento. $4^{\mathrm{a}}$ ed., Campinas: Pontes, 2006.

PRECIADO, B. Sujeira e gênero. Mijar/Cagar. Masculino/Feminino. Basura y género. Mear/cagar. Masculino/femenino. 2006. Disponível em: < http://www.substantivoplural .com.br/sujeira-e-genero-mijarcagar-masculinofeminino-por-beatriz-preciado/>. Acesso em: 02 de dez. de 2017.

SAFATLE, V. Dos problemas de gênero a uma teoria da despossessão necessária: ética, política e reconhecimento em Judith Butler (posfácio). In: BUTLER, J. Relatar a si mesmo. Crítica da violência ética. Trad. Rogério Bettoni. Belo Horizonte: Autêntica Editora, 2015.

SOUSA, Lucília Maria Abrahão. O real e a poesia nos entremeios litorâneos de Pêcheux e Lacan. Fragmentum. Santa Maria: Programa de Pós-graduação em Letras, UFSM, n. 47, Jan./Jun. 2016.

SCOTT, J. W. [1986]. Gênero: uma categoria útil de análise histórica. In: Educação \& Realidade. Porto Alegre, vol. 20, n. 2, jul-dez, 1995, p. 71-99.

TELLES, Cynara Maria Andrade et al. O sujeito-criança na rede eletrônica: movimentos de sentidos. Texto Digital, Florianópolis, v. 7, n. 1, jan./jun. 2011. p. 1336. 


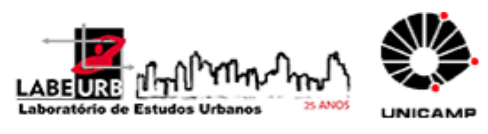

\section{Para citar essa obra:}

BOCHI et al. WC e gênero: discursos em movimento. In: RUA [online]. $\mathrm{n}^{\circ}$. 24. Volume 1 - p. 281-304 - e-ISSN 2179-9911 - junho/2018. Consultada no Portal Labeurb - Revista do Laboratório de Estudos Urbanos do Núcleo de Desenvolvimento da Criatividade.

http://www.labeurb.unicamp.br/rua/

Capa: Fonte: Google Imagens

Laboratório de Estudos Urbanos - LABEURB

Núcleo de Desenvolvimento da Criatividade - NUDECRI

Universidade Estadual de Campinas - UNICAMP

http://www.labeurb.unicamp.br/

Endereço:

LABEURB - LABORATÓRIO DE ESTUDOS URBANOS

UNICAMP/COCEN / NUDECRI

CAIXA POSTAL 6166

Campinas/SP - Brasil

CEP 13083-892

Fone/ Fax: (19) 3521-7900

Contato: http://www.labeurb.unicamp.br/contato 